\title{
EFFECT OF PACKAGING AND SEASON OF MILK PRODUCTION ON SELECTED QUALITY CHARACTERISTICS OF ORGANIC ACID CURD CHEESE DURING STORAGE
}

\author{
Małgorzata Jasińska ${ }^{\bowtie}$, Katarzyna Harabin, Izabela Dmytrów \\ Department of Dairy Technology and Food Storage, West Pomeranian University of Technology in Szczecin \\ Papieża Pawła VI/3, 71-459 Szczecin, Poland
}

\begin{abstract}
Background. This study aimed to estimate the effect of the season of milk production and the packaging method on sensory characteristics and some physicochemical indices of fresh curd cheese stored in cooling conditions.

Material and methods. This study covered three seasons: autumn (October), winter (January) and spring (March/April). The experimental samples were vacuum packed in 50 or $100 \mu \mathrm{m}$ PE film, or in parchment paper and 50 or $100 \mu \mathrm{m}$ PE film. The evaluation was made on the day of production of the cheese and after $3,7,14$ and 21 days of cold storage. The tvarogs were subjected to the sensory evaluation, and also the investigation of moisture content, fat content, acidity, $\mathrm{pH}$, hardness and the percentage of whey leakage was carried out.

Result. It was found that among the sensory characteristics the deterioration in odour occurred first in the course of storage, regardless of the packaging method applied. The method of packaging exerted no clear effect on moisture content, fat content and hardness of tvarogs. However, wrapping tvarogs additionally in parchment paper increased whey leakage, but also favourably affected cheese structure and consistency.

Conclusions. Tvarog packed in parchment paper and $100 \mu \mathrm{m}$ PE film had the most desirable sensory characteristics in the course of storage. The shelf-life of the studied tvarog cheeses was as long as 7 days, regardless of the packaging method used and season of milk production.
\end{abstract}

Key words: acid curd cheese (tvarog), method of packaging, season

\section{INTRODUCTION}

Fresh curd cheeses (acid curd cheeses, tvarogs, cottage cheeses) count among traditional dairy products. The technology of their production varies in different regions and different dairy traditions all over the world. For this reason, white fresh cheeses have strongly varied quality characteristics, especially those concerning their chemical composition and sensory characteristics [Bohdziewicz 2009]. They are regarded high quality products in our diet, that are rich in protein, macro elements, organic acids and vitamins [Szpendowski et al. 2005].

Short shelf-life is considered the greatest fault of fresh curd cheeses. For tvarogs wrapped in parchment paper and stored in refrigerated conditions, shelf-life varies from 2 to 4 days, depending on the initial quality of the product. Such a short shelf-life results, on one hand, from the chemical composition of the product, and on the other hand from the type of

${ }^{\otimes}$ malgorzata.jasinska@zut.edu.pl 
packaging, which not always provides sufficient protection against microbiological and chemical contamination or mechanical damage [Panfil-Kuncewicz and Kuncewicz 1996].

Optimal parameters of protection for fresh curd cheeses can be obtained due to a wide assortment of plastic wraps available on the market and their varied barrier properties. Vacuum packing and modified atmosphere packing proved to be a particular improvement over the previous methods of fresh curd cheeses packaging [Pluta et al. 2003, Ziółkowski et al. 2004, Pikul et al. 2006]. Panfil-Kuncewicz [2010] revealed that vacuum packing and modified atmosphere packing of fresh curd cheeses increased their shelf-life from 5-fold to 8-fold compared to conventional packing in parchment paper.

Recently, a growing number of consumers are interested in organic food due to its sensory characteristics and nutritional value. Organic food products are manufactured on a small scale in small factories, at the lowest possible cost, and therefore they require a relatively cheap and easy to use method of packaging. Regarding the above, this study aimed to estimate the effect of packaging method and season of milk production on sensory characteristics and some physicochemical indices in organic fresh curd cheese stored in refrigerated conditions.

\section{MATERIAL AND METHODS}

The subject of this study was fresh curd cheese (tvarog) produced by a conventional technology, in autumn (October), winter (January) and spring (in March and April), at an organic farm located in Western Pomerania, Poland. Polyethylene (PE) was chosen as a packaging material, because it is one of the most common plastics, its popularity deriving among others from its low price. The tvarog cheese samples were packaged in PE film from 50 to $100 \mu \mathrm{m}$ thick or in both parchment paper and PE film from 50 to $100 \mu \mathrm{m}$ thick. The cheeses were produced using organic milk of Holstein-Friesian cows, purified, not-normalized and pasteurised. According to the milk producer's data, the total number of microorganisms in the raw milk in all three seasons equalled 10000 per $1 \mathrm{~cm}^{3}$, while the number of somatic cells in $1 \mathrm{~cm}^{3}$ was varied and amounted to 175000 in autumn, 260000 in winter and 100000 in spring. The productivity of the herd of 80 cows was 45000 liters of milk per month.

Directly after being manufactured, the cheeses were transported in refrigerated conditions to the Department of Dairy Technology and Food Storage at the West Pomeranian University of Technology in Szczecin. The cheeses were divided into pieces weighing approximately $150 \mathrm{~g}$ each and packaged in vacuum (underpressure 15 mbar for $2.5 \mathrm{~s}$ and "soft-air" option at the level of 400 mbar) [Dmytrów et al. 2007]. The following variants of experimental samples were prepared:

- tvarog packaged in $50 \mu \mathrm{m}$ PE film

- tvarog packaged in parchment paper and $50 \mu \mathrm{m} \mathrm{PE}$ film

- tvarog packaged in $100 \mu \mathrm{m}$ PE film

- tvarog packaged in parchment paper and $50 \mu \mathrm{m} \mathrm{PE}$ film.

Due to an insufficient amount of cheese produced in autumn, this study lacks autumn samples of tvarog packaged in $100 \mu \mathrm{m}$ PE film. The packaged cheese samples were stored at the temperature of $5 \pm 1^{\circ} \mathrm{C}$ for 21 days, and were taken for analysis on the day of production, as well as after 3, 7, 14 and 21 days of storage. The following parameters were determined in the examined cheeses according to the Polish Standard PN-73/A-86232: moisture content by oven-drying, fat content by the Gerber method, titratable acidity in ${ }^{\circ} \mathrm{SH}$, and $\mathrm{pH}$ using an IQ $150 \mathrm{pH}-$-meter from Scientific Instruments Inc.

Moreover, hardness of tvarogs was determined by the double compression test TPA using a TA.XT plus texture analyser from Stable Micro System, applying an aluminium rod of $6 \mathrm{~mm}$ in diameter, pressure of $1 \mathrm{G}$, penetration depth of $20 \mathrm{~mm}$ and velocity of $5 \mathrm{~mm} \cdot \mathrm{s}^{-1}$. Each time the amount of whey leakage was measured by weighing (to the nearest $0.01 \mathrm{~g}$ ) the cheese with packaging and after removing the packaging. Afterwards the packaging was dried with a paper towel and also weighed; the percentage of whey leakage was calculated from the weight difference [Ziólkowski et al. 2004].

Evaluation of sensory characteristics of tvarogs was carried out using a five point scale. Flavour, odour, colour, structure and consistency were evaluated according to standards PN-ISO 4121:1998 and PN-ISO 11036:1999. The evaluation was made by a 4-person 
panel of tasters, examined for sensitivity of taste and experienced in sensory evaluation of dairy products.

The presented results are arithmetic means from three replicates, or in the case of hardness from nine replicates, and were processed statistically with the Microsoft Excel spreadsheet, on the basis of tests (t-Student's test, Cochran-Cox test) that examine differences between two independent or dependent sample means. All tests were conducted at the significance level of $\alpha=0.05$.

\section{RESULTS AND DISCUSSION}

The results indicate that the thickness of PE film, the use of parchment paper and the season of milk production had different effect on sensory characteristics of the experimental tvarog cheeses (Table 1). All these factors had practically no effect on colour of the cheese, that did not change for the whole storage period; the only exception was tvarog produced in winter, packaged in $50 \mu \mathrm{m}$ PE film and stored for 21 days (mould on the surface of cheese appeared), because unsealing its packaging between the $14^{\text {th }}$ and $21^{\text {st }}$ day of storage had resulted in deterioration of all characteristics considered in the sensory evaluation in the examined time point. The flavour and odour of all the examined cheeses were found very good only during the initial 3 days of cold storage, after that time the characteristics were observed to deteriorate. This applies especially to odour, which was becoming untypical, impure, musty and yeasty. The progress of undesirable changes was slower in cheeses packed in $100 \mu \mathrm{m}$ PE film, compared to those packed in $50 \mu \mathrm{m}$ PE film. After 21 days of cold storage, a majority of cheese samples were not suitable for consumption due to a negative odour and flavour.

The structure and consistency of the examined tvarogs were scored high, and no clear effect of packaging method or season of milk production on these characteristics was detected. The most uniform and compact consistency was observed for tvarog packed in parchment paper and $100 \mu \mathrm{m}$ PE film. At the same time it was observed that in winter sensory characteristics of tvarogs were worse than in the other two seasons, regardless of the method of packaging applied. To some extent this could be associated with the highest number of somatic cells contained in the milk produced in winter $\left(260000 / \mathrm{cm}^{3}\right)$. As reported by Danków [2000], the number of somatic cells within $200 \quad 000-400 \quad 000 / \mathrm{cm}^{3}$ indicates that udder health in the barn is compromised, and there are sick cows in the herd. This study revealed that the most desirable flavour, odour, structure and consistency were the attributes of tvarogs packed in parchment paper and $100 \mu \mathrm{m}$ PE film.

A study of Dmytrów et al. [2007] revealed that the type of plastic film used for packaging: $40 \mu \mathrm{m} \mathrm{PE} /$ PA (polyamide) without EVOH (Ethylene Vinyl Alcohol Copolymer) and $80 \mu \mathrm{m} \mathrm{PE} / \mathrm{EVOH} / \mathrm{PA}$, had no effect on sensory characteristics of acid curd cheese during storage. Pluta et al. [2003] reported that industrially produced tvarogs, that were vacuum packaged in PE/PA film without atmosphere modification or in the atmosphere of inert gases, were evaluated as good even after 21 days of storage at $10^{\circ} \mathrm{C}$.

\section{Whey leakage}

The amount of whey leakage from tvarogs was varied in the course of storage and ranged from $0.2 \%$ to $12.95 \%$ (Fig. 1). In most cases, tvarogs produced in spring were distinguished by the smallest leakage of whey. This could have been a result of lower initial moisture content in those cheeses, compared to the other samples. The greatest leakage of whey occurred during the initial seven days of the study, and was distinctly greater in the case of tvarogs packed additionally in parchment paper. This was caused by absorption of certain amount of water from the cheese by the paper. In the course of further storage, changes in the amount of whey leakage were smaller, and for the majority of the examined cheeses leakage of whey after 21 days of storage was smaller than after 14 days. Also the thickness of PE film used for packaging of tvarogs had some effect on the amount of whey leakage. Tvarogs packed in $100 \mu \mathrm{m}$ PE film were distinguished by a greater whey leakage compared to tvarogs packed in $50 \mu \mathrm{m}$ PE film, that might have been a result of a higher barrier capacity of thicker PE film and its lower permeability to water vapour.

Cais and Wojciechowski [1996] implied that storage of tvarogs at the temperature below $8^{\circ} \mathrm{C}$ might lead to water retention as a result of an excessively advanced process of physical ripening of cheese. This process involves, inter alia, protein swelling 
Jasińska M., Harabin K., Dmytrów I., 2014. Effect of packaging and season of milk production on selected quality characteristics of organic acid curd cheese during storage. Acta Sci. Pol., Technol. Aliment. 13(3), 231-242.

Table 1. Scores awarded during sensory evaluation of tvarog during 21 days of cool storage (5-point scale)

\begin{tabular}{|c|c|c|c|c|c|c|c|c|c|c|c|c|c|c|c|c|c|c|c|c|}
\hline \multirow{3}{*}{$\begin{array}{l}\text { Quality } \\
\text { factor }\end{array}$} & \multicolumn{5}{|c|}{$\mathrm{T}+50$} & \multicolumn{5}{|c|}{$\mathrm{TP}+50$} & \multicolumn{5}{|c|}{$\mathrm{T}+100$} & \multicolumn{5}{|c|}{$\mathrm{TP}+100$} \\
\hline & \multicolumn{20}{|c|}{ storage time, days } \\
\hline & 0 & 3 & 7 & 14 & 21 & 0 & 3 & 7 & 14 & 21 & 0 & 3 & 7 & 14 & 21 & 0 & 3 & 7 & 14 & 21 \\
\hline
\end{tabular}

Colour

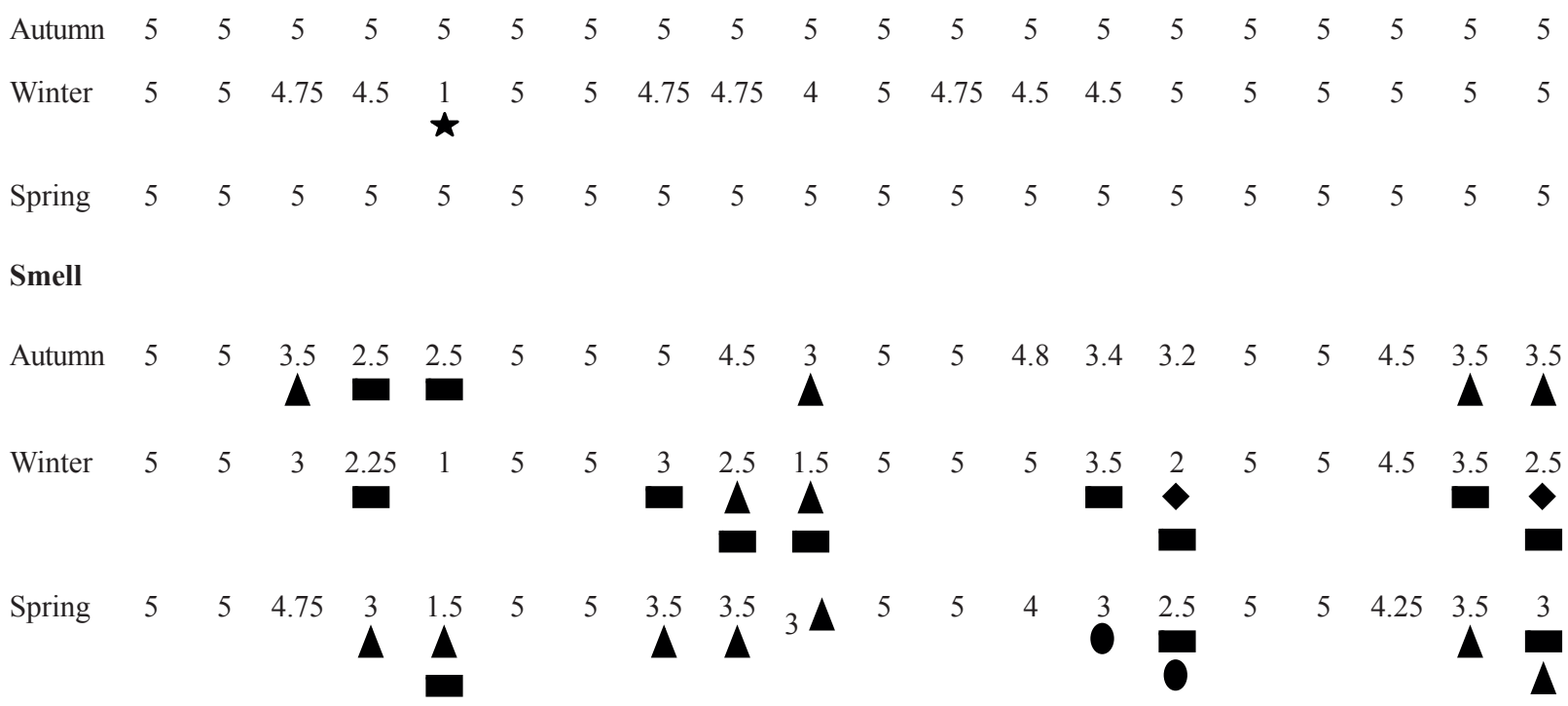

Taste

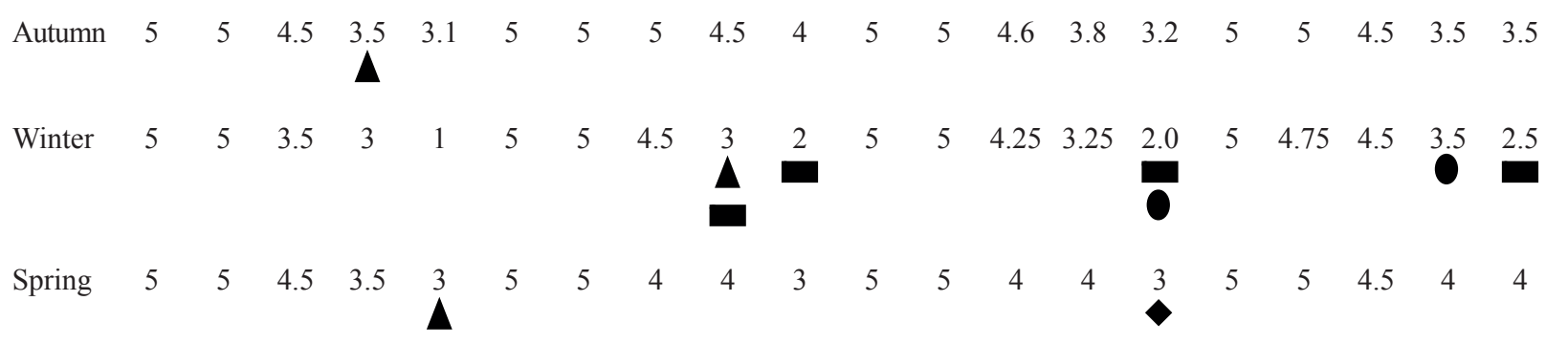

Texture

\begin{tabular}{lcccccccccccccccccccc} 
Autumn & 5 & 5 & 4 & 3.5 & & 5 & 5 & 4.5 & 4 & & 5 & 5 & 4.7 & 4 & 4 & 5 & 5 & 4.5 & 4 & 4 \\
Winter & 5 & 5 & 4.5 & 4 & 4 & 5 & 4.75 & 4 & 4 & 4.25 & 5 & 5 & 5 & 4.5 & 4 & 5 & 5 & 5 & 5 & 4.5 \\
Spring & 5 & 5 & 4.5 & 4 & 4 & 5 & 5 & 5 & 5 & 5 & 5 & 5 & 5 & 4 & 4 & 5 & 5 & 5 & 5 & 4.5 \\
\hline
\end{tabular}

- yeasty , $\mathbf{\Delta}$ - impure, $\mathbf{\square}$-musty, $\boldsymbol{\nabla}$ - slightly bitter, $\star$ - mould.

$\mathrm{T}+50$ - tvarog packed in $50 \mu \mathrm{m}$ PE film, $\mathrm{T}+100$ - tvarog packed in $100 \mu \mathrm{m}$ PE film, TP +50 - tvarog packed in parchment paper and $50 \mu \mathrm{m}$ PE film, TP + 100 - tvarog packed in parchment paper and $100 \mu \mathrm{m}$ PE film. 
Jasińska M., Harabin K., Dmytrów I., 2014. Effect of packaging and season of milk production on selected quality characteristics of organic acid curd cheese during storage. Acta Sci. Pol., Technol. Aliment. 13(3), 231-242.
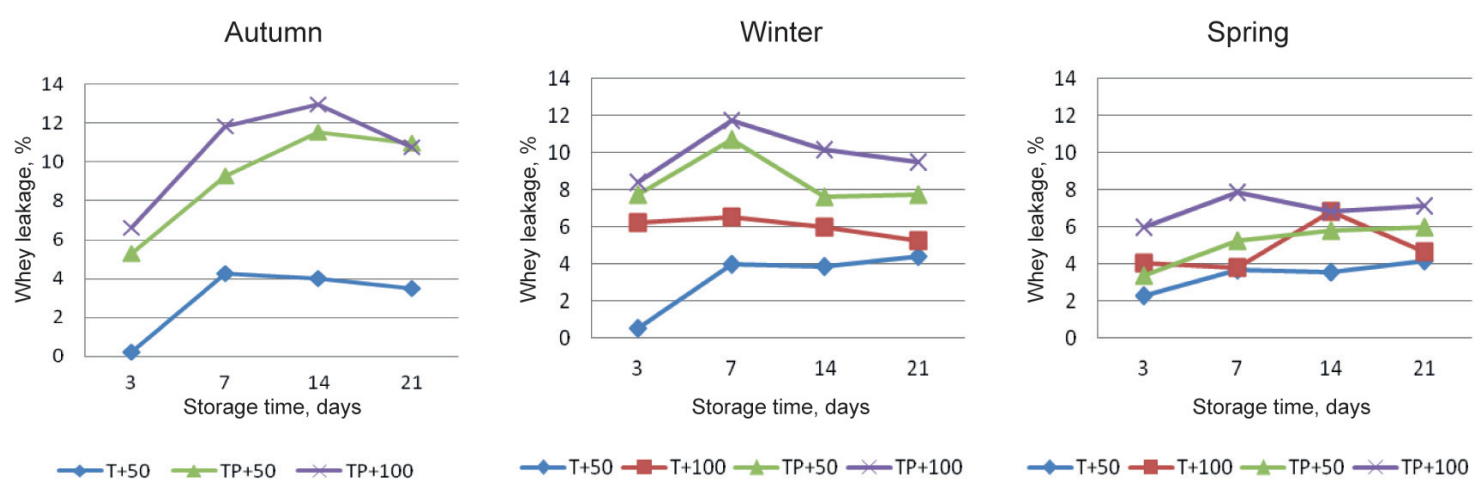

Fig. 1. Effect of the packaging method on whey leakage from acid-curd cheeses (tvarogs) stored under cooling conditions $\left(5 \pm 1{ }^{\circ} \mathrm{C}\right): \mathrm{T}+50$ - tvarog packed in $50 \mu \mathrm{m}$ PE film, $\mathrm{T}+100$ - tvarog packed in $100 \mu \mathrm{m}$ PE film, TP +50 - tvarog packed in parchment paper and $50 \mu \mathrm{m}$ PE film, TP + 100 - tvarog packed in parchment paper and $100 \mu \mathrm{m}$ PE film

and trapping free water. On the contrary, Pikul et al. [2006] reported that in tvarogs wraped in Eco Lean film and packed in vacuum sealed PA/PE bags the amount of whey leakage was increasing during 24 days of storage at $5 \pm 1{ }^{\circ} \mathrm{C}$. Similarly, Pluta et al. [2003] reported an increasing amount of whey leakage from tvarogs packed in PE/PA bags during 21 days of storage, but at $10^{\circ} \mathrm{C}$.

\section{Moisture content}

The initial moisture content in tvarogs produced in autumn and winter were very similar and slightly higher than in cheeses produced in spring (Fig. 2).
During storage, moisture content in the examined tvarogs ranged within $61.5-71.84 \%$. Moisture content in tvarogs after 21 days of storage was usually lower compared to the initial value; only in two cases the final moisture content was slightly higher than the initial value - in the winter tvarog packed in $50 \mu \mathrm{m} \mathrm{PE}$ film and in the spring tvarog packed in $100 \mu \mathrm{m} \mathrm{PE}$ film. The differences between the initial and final (after 21 days of storage) values of moisture content were statistically significant in autumn tvarogs packed in parchment paper and $100 \mu \mathrm{m}$ PE film, winter tvarogs packed in parchment paper and $50 \mu \mathrm{m}$ PE film, and spring tvarogs packed in parchment paper and $50 \mu \mathrm{m}$
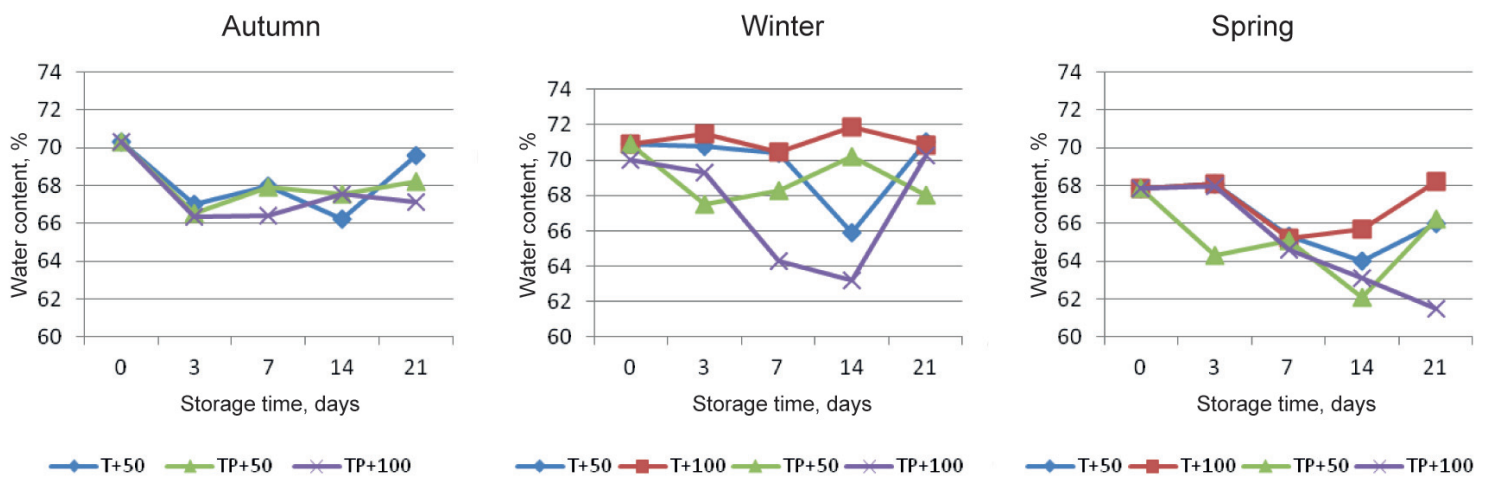

Fig. 2. Effect of the packaging method on water content in acid-curd cheeses (tvarogs) stored under cooling conditions $\left(5 \pm 1^{\circ} \mathrm{C}\right)$. Explanations see Figure 1 
PE film and parchment paper and $100 \mu \mathrm{m}$ PE film (Table 2). The conducted statistical analysis revealed that packaging method had no clear effect on moisture content in tvarogs produced in autumn and spring. In winter, however, there were significant differences between tvarogs in parchment paper packed in $50 \mu \mathrm{m}$ $\mathrm{PE}$ film and $100 \mu \mathrm{m}$ PE film, as well as between tvarogs with and without parchment paper packed in $100 \mu \mathrm{m}$ PE film (Table 3, 4, 5).

Table 2. Results of the statistical analysis of the dependent mean values verifying influence of time on some physicochemical indicators of tvarogs stored for 21 days under cooling condition (Student's t-test)

\begin{tabular}{|c|c|c|c|c|}
\hline $\begin{array}{l}\text { Physicochemical } \\
\text { indicators }\end{array}$ & $\mathrm{T}+50$ & $\mathrm{~T}+100$ & $\mathrm{TP}+50$ & $\mathrm{TP}+100$ \\
\hline \multicolumn{5}{|c|}{$t$ autumn } \\
\hline Water content & 3.219 & - & 3.943 & $26.318 *$ \\
\hline Fat content & 1.000 & - & 1.000 & $11.000 *$ \\
\hline Titratable acidity & $\Omega$ & - & $\Omega$ & 4.000 \\
\hline $\mathrm{pH}$ & 1.857 & - & $21.166^{*}$ & $10.000 *$ \\
\hline Hardness & 1.602 & - & $4.711 *$ & $5.812^{*}$ \\
\hline \multicolumn{5}{|c|}{$t$ winter } \\
\hline Water content & 0.771 & 0.189 & $8.021^{*}$ & 1.716 \\
\hline Fat content & $6.500^{*}$ & $5.196^{*}$ & $13.000 *$ & $10.961 *$ \\
\hline Titratable acidity & $8.000 *$ & $\Omega$ & 1.000 & $6.928^{*}$ \\
\hline $\mathrm{pH}$ & $7.843^{*}$ & $8.718^{*}$ & 0.397 & $7.069^{*}$ \\
\hline Hardness & $5.944^{*}$ & $10.996^{*}$ & $5.735^{*}$ & $11.194 *$ \\
\hline \multicolumn{5}{|c|}{$t$ spring } \\
\hline Water content & 3.065 & 0.434 & $8.170^{*}$ & $12.753 *$ \\
\hline Fat content & 1.732 & $\Omega$ & $\Omega$ & $\Omega$ \\
\hline Titratable acidity & $7.000^{*}$ & 1.732 & 0.378 & 0.898 \\
\hline $\mathrm{pH}$ & $29.676^{*}$ & $134.00^{*}$ & $51.403 *$ & $72.746^{*}$ \\
\hline Hardness & $8.160 *$ & 2.214 & $2.414^{*}$ & $11.444 *$ \\
\hline
\end{tabular}

$t$ - value of statistical testing, $t \alpha$ - critical value for significance level $\alpha=0.05$ ( $t \alpha=2.306$ for hardness and 4.303 for the other indicators), $\Omega$-inability to perform the test. Other explanations see Table 1.

*Significant differences.
For the majority of the examined cheeses, moisture content was found to increase between the $14^{\text {th }}$ and $21^{\text {st }}$ day of storage, that was often combined with a reduced whey drainage. This would confirm the suggestion of Cais and Wojciechowski [1996] on an increased water absorption capacity of proteins during physical ripening of cheese. Microbiological quality of fresh curd cheeses may influence moisture content as well. Steinka [2003] observed that changes in moisture content in tvarogs of high microbiological quality were significantly different compared to tvarogs with considerable microbiological contamination.

Table 3. Results of the statistical analysis of the independent mean values veryfying influence of packaging on some physicochemical indicators of tvarogs stored under cooling conditions (in autumn)

\begin{tabular}{|c|c|c|c|c|}
\hline \multirow{2}{*}{$\begin{array}{l}\text { Packaging method } \\
\text { of tvarog }\end{array}$} & \multicolumn{4}{|c|}{ Value of statistical testing $t$ after } \\
\hline & 3 days & 7 days & 14 days & 21 days \\
\hline \multicolumn{5}{|c|}{ Water content } \\
\hline $\mathrm{TP}+50-\mathrm{TP}+100$ & 0.653 & 2.254 & 0.008 & 1.802 \\
\hline $\mathrm{T}+50-\mathrm{TP}+50$ & 0.881 & 0.097 & $5.201 *$ & 2.067 \\
\hline \multicolumn{5}{|c|}{ Fat content } \\
\hline $\mathrm{TP}+50-\mathrm{TP}+100$ & $4.366^{*}$ & 1.809 & $4.523 *$ & $3.780^{*}$ \\
\hline $\mathrm{T}+50-\mathrm{TP}+50$ & $12.728^{*}$ & 1.512 & 1.147 & 0.905 \\
\hline \multicolumn{5}{|c|}{ Titratable acidity } \\
\hline $\mathrm{TP}+50-\mathrm{TP}+100$ & $157.1^{*}$ & 1.000 & 2.236 & $\Omega$ \\
\hline $\mathrm{T}+50-\mathrm{TP}+50$ & 1.069 & 0.000 & 2.000 & $\Omega$ \\
\hline \multicolumn{5}{|c|}{$\mathrm{pH}$} \\
\hline $\mathrm{TP}+50-\mathrm{TP}+100$ & $9.546^{*}$ & 1.768 & 0.125 & $8.222 *$ \\
\hline $\mathrm{T}+50-\mathrm{TP}+50$ & 1.697 & 1.698 & 0.508 & $11.193 *$ \\
\hline \multicolumn{5}{|c|}{ Hardness } \\
\hline $\mathrm{TP}+50-\mathrm{TP}+100$ & $9.807^{*}$ & 0.982 & $4.523^{*}$ & 0.129 \\
\hline $\mathrm{T}+50-\mathrm{TP}+50$ & $5.437^{*}$ & $5.264^{*}$ & 0.960 & $2.825^{*}$ \\
\hline
\end{tabular}

$t \alpha-$ critical value for significance level $\alpha=0.05(t \alpha=2.131$ for hardness and 2.776 for the other indicators). Other explanations see Table 1 and 2. 
Jasińska M., Harabin K., Dmytrów I., 2014. Effect of packaging and season of milk production on selected quality characteristics of organic acid curd cheese during storage. Acta Sci. Pol., Technol. Aliment. 13(3), 231-242.

Table 4. Results of the statistical analysis of the independent mean values veryfying influence of packaging on some physicochemical indicators of tvarogs stored under cooling conditions (in winter)

\begin{tabular}{lllll}
\hline \multirow{2}{*}{$\begin{array}{c}\text { Packaging method } \\
\text { of tvarog }\end{array}$} & \multicolumn{3}{c}{ Value of statistical testing $t$ after } \\
\cline { 2 - 3 } & 3 days & 7 days & 14 days & 21 days \\
\hline
\end{tabular}

\begin{tabular}{ccccc}
\hline \multicolumn{5}{c}{ Water content } \\
$\mathrm{T}+50-\mathrm{T}+100$ & 0.333 & 0.066 & $8.596^{*}$ & 0.339 \\
$\mathrm{~T}+100-\mathrm{TP}+100$ & $4.998^{*}$ & $16.504^{*}$ & $12.958^{*}$ & 1.095 \\
$\mathrm{TP}+50-\mathrm{TP}+100$ & $7.906^{*}$ & $12.993^{*}$ & $2.979^{*}$ & $4.934^{*}$ \\
$\mathrm{~T}+50-\mathrm{TP}+50$ & 0.400 & 0.000 & 1.483 & $\Omega$
\end{tabular}

Fat content

$\begin{array}{ccccc}\mathrm{T}+50-\mathrm{T}+100 & 4.919 * & 2.111 & 6.247 * & 2.000 \\ \mathrm{~T}+100-\mathrm{TP}+100 & 0.905 & 21.019 * & 11.717 * & 19.000 * \\ \mathrm{TP}+50-\mathrm{TP}+100 & 2.411 & 38.184 * & 5.160 * & \Omega \\ \mathrm{T}+50-\mathrm{TP}+50 & 0.400 & 0.000 & 1.483 & \Omega\end{array}$

Titratable acidity

$\begin{array}{ccccc}\mathrm{T}+50-\mathrm{T}+100 & 0.945 & \Omega & 2.828 & \Omega \\ \mathrm{T}+100-\mathrm{TP}+100 & \Omega & \Omega & 0.000 & 0.000 \\ \mathrm{TP}+50-\mathrm{TP}+100 & \Omega & 1.604 & \Omega & \Omega \\ \mathrm{T}+50-\mathrm{TP}+50 & 1.000 & \Omega & \Omega & \Omega \\ & \mathrm{pH} & & & \\ \mathrm{T}+50-\mathrm{T}+100 & 2.806^{*} & 1.323 & 10.253^{*} & 14.783^{*} \\ \mathrm{~T}+100-\mathrm{TP}+100 & 3.207^{*} & 5.237^{*} & \Omega & 1.250 \\ \mathrm{TP}+50-\mathrm{TP}+100 & 7.071^{*} & 3.212^{*} & \Omega & 6.571^{*} \\ \mathrm{~T}+50-\mathrm{TP}+50 & 1.838 & 0.588 & 3.130^{*} & 8.000^{*}\end{array}$

Hardness

\begin{tabular}{ccccc}
$\mathrm{T}+50-\mathrm{T}+100$ & $5.006^{*}$ & 1.612 & $4.729 *$ & $7.339^{*}$ \\
$\mathrm{~T}+100-\mathrm{TP}+100$ & $4.374 *$ & $2.948^{*}$ & $8.950^{*}$ & $2.625^{*}$ \\
$\mathrm{TP}+50-\mathrm{TP}+100$ & 1.456 & $2.619^{*}$ & $4.044^{*}$ & $4.865^{*}$ \\
$\mathrm{~T}+50-\mathrm{TP}+50$ & $9.516^{*}$ & $3.652^{*}$ & 0.283 & $2.591^{*}$ \\
\hline
\end{tabular}

Explanations see Table 1 and 2.
Table 5. Results of the statistical analysis of the independent mean values veryfying influence of packaging on some physicochemical indicators of tvarogs stored under cooling conditions (in spring)

\begin{tabular}{ccccc}
\hline \multirow{2}{*}{$\begin{array}{c}\text { Packaging method } \\
\text { of tvarog }\end{array}$} & \multicolumn{4}{c}{ Value of statistical testing $t$ after } \\
\cline { 2 - 5 } & 3 days & 7 days & 14 days & 21 days \\
\hline \multirow{4}{*}{ Water content } & & \\
$\mathrm{T}+50-\mathrm{T}+100$ & 0.032 & 0.216 & $3.049^{*}$ & $3.785^{*}$ \\
$\mathrm{~T}+100-\mathrm{TP}+100$ & $\Omega$ & 0.629 & $5.572^{*}$ & $14.862^{*}$ \\
$\mathrm{TP}+50-\mathrm{TP}+100$ & $\Omega$ & 0.588 & 2.015 & $17.392^{*}$ \\
$\mathrm{~T}+50-\mathrm{TP}+50$ & $3.094^{*}$ & 0.360 & $3.208^{*}$ & 0.483
\end{tabular}

Fat content

$\begin{array}{ccccc}\mathrm{T}+50-\mathrm{T}+100 & 4.158^{*} & 1.565 & 1.265 & 2.085 \\ \mathrm{~T}+100-\mathrm{TP}+100 & 2.646 & 3.354^{*} & \Omega & \Omega \\ \mathrm{TP}+50-\mathrm{TP}+100 & 2.646 & 11.314 * & \Omega & \Omega \\ \mathrm{T}+50-\mathrm{TP}+50 & 4.158^{*} & 4.243 & 0.866 & \Omega\end{array}$

Titratable acidity

$\begin{array}{ccccc}\mathrm{T}+50-\mathrm{T}+100 & 1.414 & \Omega & 10.253^{*} & \Omega \\ \mathrm{T}+100-\mathrm{TP}+100 & 0.500 & \Omega & 9.950^{*} & 1.569 \\ \mathrm{TP}+50-\mathrm{TP}+100 & 9.798^{*} & 3.130^{*} & 0.000 & 1.084 \\ \mathrm{~T}+50-\mathrm{TP}+50 & 12.500^{*} & 3.536^{*} & 1.789 & \Omega \\ \mathrm{pH} & & & \\ \mathrm{T}+50-\mathrm{T}+100 & 9.339^{*} & 0.000 & 1.265 & 4.930^{*} \\ \mathrm{~T}+100-\mathrm{TP}+100 & 11.926^{*} & 0.894 & 0.632 & 2.530 \\ \mathrm{TP}+50-\mathrm{TP}+100 & 8.000^{*} & 2.673 & 0.500 & 3.536^{*} \\ \mathrm{~T}+50-\mathrm{TP}+50 & 16.843^{*} & 4.243^{*} & 2.500 & 5.480^{*}\end{array}$

Hardness

\begin{tabular}{ccccc}
$\mathrm{T}+50-\mathrm{T}+100$ & $2.765^{*}$ & 1.844 & $13.802^{*}$ & $8.840^{*}$ \\
$\mathrm{~T}+100-\mathrm{TP}+100$ & $6.548^{*}$ & $3.788^{*}$ & $14.522^{*}$ & $12.593^{*}$ \\
$\mathrm{TP}+50-\mathrm{TP}+100$ & $7.816^{*}$ & $3.591 *$ & 1.885 & $8.974^{*}$ \\
$\mathrm{~T}+50-\mathrm{TP}+50$ & 0.318 & 1.394 & $3.708^{*}$ & $5.101^{*}$ \\
\hline
\end{tabular}

Explanations see Table 1 and 2. 


\section{Fat content}

The average fat content in the examined cheeses varied from $9.03 \%$ (winter tvarog packed in parchment paper and $50 \mu \mathrm{m}$ PE film) to $14.23 \%$ (spring tvarog packed in parchment paper and $100 \mu \mathrm{m}$ PE film; Fig. 3). Tvarogs produced in spring were the highest in fat. However, the presence of considerable differences in fat content in the course of storage is difficult to explain. It can be only assumed that the cheeses differed in the initial fat content. Statistically significant differences in fat content were found between autumn tvarogs in parchment paper packed in $50 \mu \mathrm{m}$ PE film and $100 \mu \mathrm{m}$ PE film, and between winter tvarogs with and without parchment paper packed in $100 \mu \mathrm{m}$ PE film. In spring tvarogs, the differences in fat content were statistically insignificant (Table 3, 4, 5). Fat content after 21 days of storage differed significantly from the initial fat level in autumn tvarogs packed in parchment paper and $100 \mu \mathrm{m}$ PE film, and in all winter tvarogs, while in spring tvarogs the difference was statistically insignificant in tvarog packed in $50 \mu \mathrm{m}$ PE. In the other tvarog samples statistical test could not be carried out (Table 2). A study of Dmytrów et al. [2007] showed that packaging had no effect on fat content in tvarogs.

\section{Titratable acidity}

Tvarogs produced in autumn and spring had similar initial acidity that amounted to 60 and $61.33^{\circ} \mathrm{SH}$, respectlively. In winter tvarogs the initial acidity was distinctly lower and amounted to $51.4^{\circ} \mathrm{SH}$ (Fig. 4).
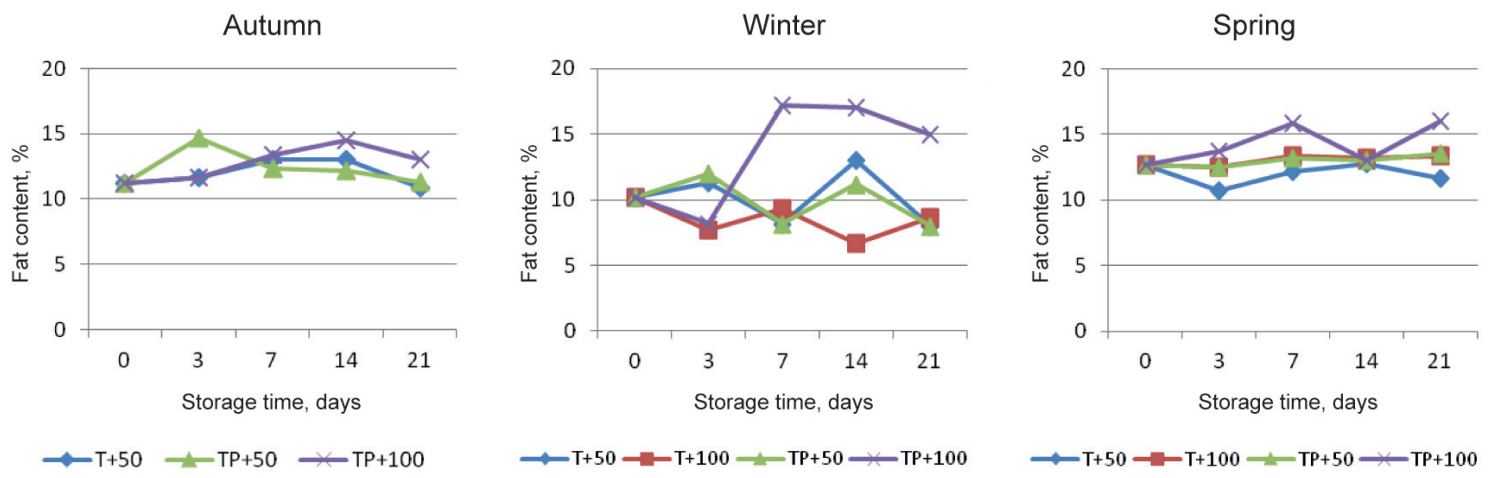

Fig. 3. Effect of the packaging method on fat content in acid-curd cheeses (tvarogs) stored under cooling conditions $\left(5 \pm 1{ }^{\circ} \mathrm{C}\right)$. Explanations see Figure 1
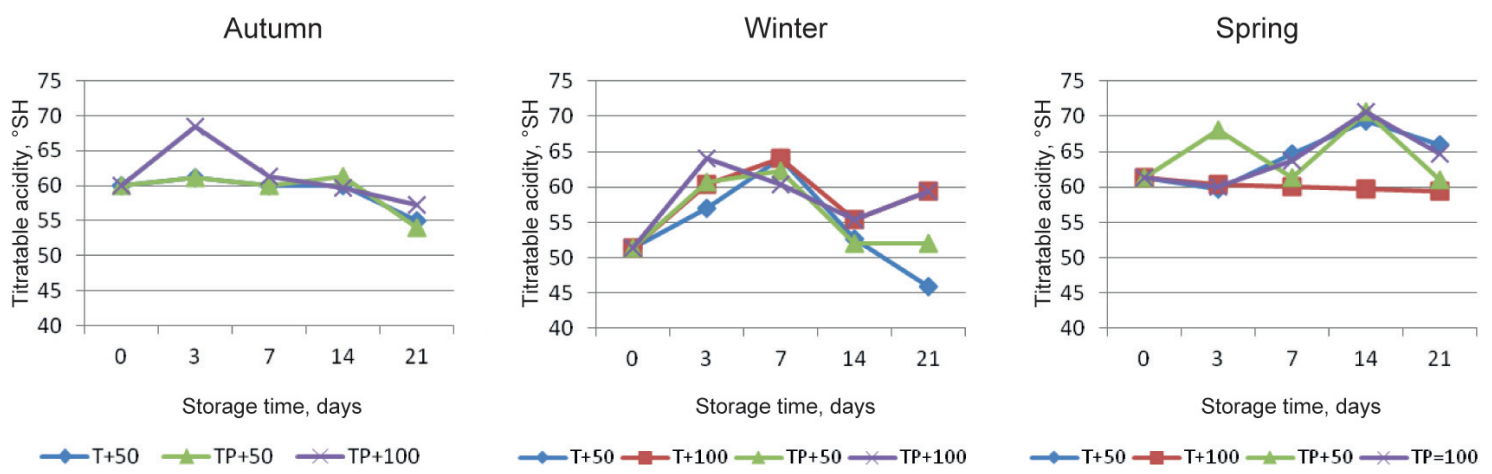

Fig. 4. Effect of the packaging method on titratable acidity acid-curd cheeses (tvarogs) stored under cooling conditions $\left(5 \pm 1{ }^{\circ} \mathrm{C}\right)$. Explanations see Figure 1 
Considerable fluctuations in acidity occurred during storage in the majority of the examined cheese samples. Relatively smallest differences in titratable acidity during storage were observed in autumn tvarogs packaged in $50 \mu \mathrm{m}$ PE film, in autumn tvarogs packaged in parchment paper and $50 \mu \mathrm{m}$ PE film, and in spring tvarogs packaged in $100 \mu \mathrm{m}$ PE film. After 14 or 21 days of storage, the titratable acidity in tvarogs decreased, that may indicate development of undesirable microflora. Only in the spring tvarogs packaged in $100 \mu \mathrm{m}$ PE film, the titratable acidity was practically unchanged for the whole study period (21 days).

No clear relationship was found between the packaging method and tvarog acidity. Differences in titratable acidity found between the examined tvarogs were not statistically significant (Table 3, 4, 5). Titratable acidity after 21 days of storage differed significantly from its initial values in winter and spring tvarogs packed in $50 \mu \mathrm{m}$ PE film, and in winter tvarogs packed in parchment paper and $100 \mu \mathrm{m}$ PE film (Table 2).

Similarly, Dmytrów et al. [2007] did not detect any clear effect of packaging material on titratable acidity of tvarogs during storage. On the contrary, a gradual increase in titratable acidity of tvarogs packed in Eco Lean and PA/PE films during 24 days of storage was reported by Pikul et al. [2006].

\section{$\mathrm{pH}$ value}

The cheeses produced in autumn, winter and spring had similar initial values of $\mathrm{pH}$ (Fig. 5). After 3 days of cold storage, $\mathrm{pH}$ decreased in all the evaluated cheese samples, while in the course of further storage $\mathrm{pH}$ fluctuated. The lowest $\mathrm{pH}$ was found in cheeses produced in spring. The method of packaging was not found to affect $\mathrm{pH}$ value in a clear way. Statistically significant differences in $\mathrm{pH}$ were observed between winter tvarogs packed with and without parchment paper, in $50 \mu \mathrm{m}$ PE film and $100 \mu \mathrm{m}$ PE film, as well as between spring tvarogs packed with and without parchment paper in $50 \mu \mathrm{m}$ PE film (Table 3, 4, 5). Differences between the initial and final (after 21 days of storage) values of $\mathrm{pH}$ were statistically significant in the majority of the examined tvarogs, exluding autumn cheeses packed in $50 \mu \mathrm{m}$ PE film and winter cheeses packed in parchment paper and $50 \mu \mathrm{m}$ PE film (Table 2).

Differently, Karczewska et al. [2005] reported that $\mathrm{pH}$ decreased throughout the whole storage period, regardless of the applied packaging (parchment paper, aluminium foil laminated to parchment paper, Eco Lean). However, it should be stressed, that in that study the period of storage was considerably shorter ( 9 days of cold storage), which might have contibuted to the differences.

\section{Hardness}

The initial hardness was similar for tvarogs produced in autumn and winter, 2.8 and $2.74 \mathrm{~N}$, respectively, while the spring cheese had higher hardness amounting to $3.34 \mathrm{~N}$. Also during storage, the highest hardness distinguished the spring cheeses, regardless of the packaging method applied (Fig. 6).
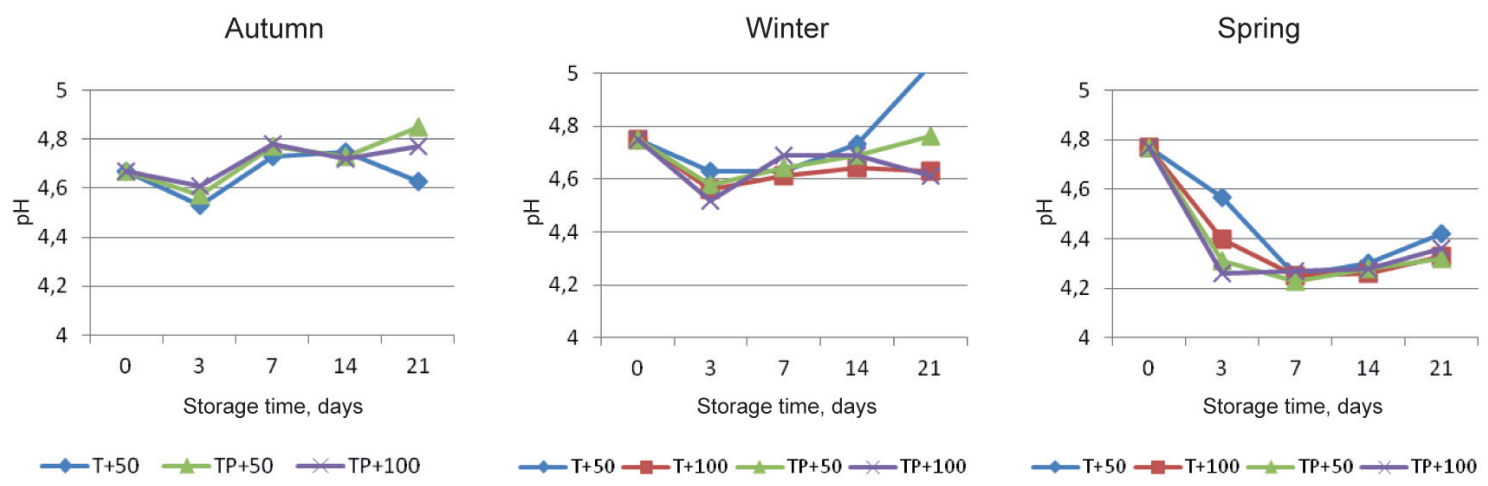

Fig. 5. Effect of the packaging method on $\mathrm{pH}$ acid-curd cheeses (tvarogs) stored under cooling conditions $\left(5 \pm 1{ }^{\circ} \mathrm{C}\right)$. Explanations see Figure 1 

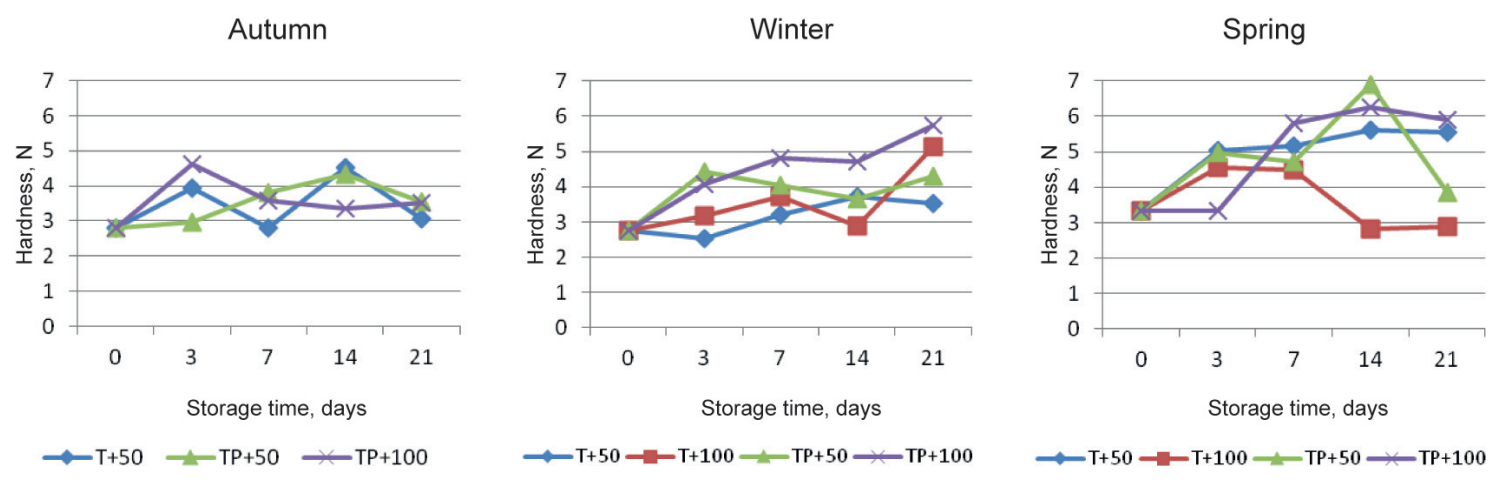

Fig. 6. Effect of the packaging method on hardness acid-curd cheeses (tvarogs) stored under cooling conditions $\left(5 \pm 1{ }^{\circ} \mathrm{C}\right)$. Explanations see Figure 1

What is worth stressing is that the method of packaging had the greatest effect on cheese hardness of all the examined indices. Statistically significant differences in hardness were observed between autumn tvarogs packed with and without parchment paper in $50 \mu \mathrm{m}$ PE film, all winter tvarogs, and most spring tvarogs; the difference between spring tvarogs packed with and without parchment paper in $50 \mu \mathrm{m}$ PE film was statistically insignificant (Table 3, 4, 5). Differences between the initial and final (after 21 days of storage) hardness were statistically significant in the majority of the examined tvarogs, exluding autumn cheeses packed in $50 \mu \mathrm{m}$ PE film and spring cheeses packed in $100 \mu \mathrm{m}$ PE film (Table 2).

Relationships among cheese hardness, moisture content and protein content have often been described in scientific publications. An increase in moisture content was reported to be accompanied by a decrease in hardness of cheese [Bonczar and Walczycka 2001, Mazur 2009]. An analogical relationship was found in this study.

Ziółkowski [2003] reported that vacuum packed tvarogs had lower hardness compared to tvarogs packed in other systems. This was attributed to a disarrangement of structure in vacuum packed tvarogs resulting from packaging and storage.

The shelf-life of the studied tvarog cheeses was as long as 7 days, regardless of the packaging method used and the season of milk production. The major limiting factor was a musty-yeasty odour of the cheese. The shelf-life was considerably shorter than in the case of industrially produced vacuum packed tvarogs, having shelf-life of 21 days [Pluta et al. 2003, Pikul et al. 2006]. In fact, presently tvarogs are usually packed in PE/PA film which has better barrier properties comparing to PE film. Spoilage of fresh curd cheeses, however, results mainly from the activity of undesirable microflora, so we can suppose that the industrial hygiene of production was considerably better than in a small factory at an organic farm, that was decisive for shelflife of the cheeses. This assumption is also in agreement with the findings of Steinka [2005], who reported that tvarogs showing the presence of yeast, enterococci and staphylococci should not be stored in air-tight PA/ PE packaging for more than 7 days.

\section{CONCLUSIONS}

1. Among the sensory characteristics, the deterioration in odour occurred first in the course of storage, regardless of the packaging method applied.

2. Tvarogs packed in parchment paper and PE film (50 or $100 \mu \mathrm{m}$ ) had better structure and consistency, compared to cheeses packed in PE film of the same thickness alone.

3. In sensory evaluation, tvarogs produced in winter were usually scored lower, compared to tvarogs produced in autumn and spring.

4. The use of parchment paper had no effect on flavour and odour of tvarogs.

5. The packaging method had no clear effect on moisture content and fat content of tvarogs. 
6. Titratable acidity and $\mathrm{pH}$ in tvarogs tended to decrease in the course of storage.

7. The packaging method and the season of milk production had no clear effect on cheese hardness.

8 . The most desirable sensory characteristics during storage distinguished the tvarogs packed in parchment paper and $100 \mu \mathrm{m}$ PE film.

\section{REFERENCES}

Bohdziewicz K., 2009. Twaróg - pierwszy świeży ser świata [Tvarog - first fresh cheese of the world]. Przegl. Mlecz. 2, 4-9 [in Polish].

Bonczar G., Walczycka M., 2001. Zależność między parametrami chemicznymi a teksturą świeżej i parzonej masy serowej z mleka owczego [Relationship between the chemical properties and texture of fresh and textured ewe,s cheese]. Żywn. Nauka Technol. Jakość 3(28), $24-$ -31 [in Polish].

Cais D., Wojciechowski J., 1996. Zmiany wybranych cech jakościowych serów twarogowych w trakcie ich przechowywania [Changes in selected quality characteristics of tvarogs in the course of their storage]. Przegl. Mlecz. 6, 177-179 [in Polish].

Danków R., 2000. Możliwości i sposoby ograniczania komórek somatycznych w mleku [Options and methods of reducing the number of somatic cells in milk]. Przegl. Mlecz. 2, 52-54 [in Polish].

Dmytrów J., Kryża K., Dmytrów K., Lisiecki S., 2007. Wpływ opakowania na wybrane cechy jakościowe sera twarogowego kwasowego przechowywanego w warunkach chłodniczych [The effect of packaging on some quality characteristics of acid curd cheese stored in refrigerated conditions]. Żywn. Nauka Technol. Jakość 1 (50), 64-76 [in Polish].

Karczewska D., Pikul J., Płuszka H., Chudy S., 2005. Zmiany wybranych cech fizyko-chemicznych tradycyjnie pakowanego twarogu w zależności od rodzaju użytego materiału opakowaniowego [Changes in physicochemical properties of selected traditionally packaged tvarog depending on the type of packaging material]. Chłodnictwo 10, 46-51 [in Polish].

Mazur J., 2009. Zmiany tekstury w trakcie przechowywania w różnych warunkach serów twarogowych kwasowych otrzymywanych metodą tradycyjną [Texture changes during storage in dfferent conditions of acid curd cheeses obtained using conventional metod]. Inż. Roln. 2 (11), 99-106 [in Polish].
Panfil-Kuncewicz H., 2010. Postęp w pakowaniu serów dojrzewających i twarogów [The progress in packaging of tvarogs and ripening cheeses]. Przegl. Mlecz. 7, 18-21 [in Polish].

Panfil-Kuncewicz H., Kuncewicz A., 1996. Nowoczesne opakowania twarogów i serów [Modern packaging of tvarogs and cheeses]. Przegl. Mlecz. 12, 366-368 [in Polish].

Pikul J., Karczewska D., Cais-Sokolińska D., Danków R., 2006. Physicochemical, microbiological and sensory changes occurring in tvarog wrapped in Eco Lean and vacuum packed during refrigerated storage. Pol. J. Food Nutr. Sci. 15/56, SI 1, 173-178.

Pluta A., Wnuk B., Ziarno M., Berthold A., 2003. Wpływ systemu pakowania twarogu na jego jakość [Effects of packaging systems on the quality of tvorog cheeses]. Żywn. Nauka Technol. Jakość 4 (37) Supl., 330-340 [in Polish].

PN-73/A-86232. Mleko i przetwory mleczarskie. Sery. Metody badań [Polish Standard PN-73/A-86232. Milk and dairy products. Cheeses. Methods of analysis; in Polish].

PN-ISO 11036:1999. Analiza sensoryczna. Metodologia. Profilowanie tekstury [PN-ISO 11036:1999. Sensory analysis. Methodology. Texture profile; in Polish].

PN-ISO 4121:1998. Analiza sensoryczna. Metodologia. Ocena produktów żywnościowych przy użyciu metod skalowania [PN-ISO 4121:1998. Sensory analysis. Methodology. Evaluation of food products by methods using scales; in Polish].

Steinka I., 2005. Wpływ jakości mikrobiologicznej twarogów na fazę wodną w warunkach pakowania hermetycznego [Influence of microbiological quality of tvorogs on water chase in conditions of hermetic packing]. Rocz. PZH 56 (3), 275-281 [in Polish].

Szpendowski J., Kłobukowski J., Prokop E., 2005. Wpływ dodatku chlorku wapnia i ogrzewania mleka na skład chemiczny serów twarogowych [The effect of calcium chloride added to milk and milk heating on the chemical composition of cottage cheeses]. Żywn. Nauka Technol. Jakość 3 (44), 36-45 [in Polish].

Ziółkowski T., 2003. Metody pakowania, a bezpieczeństwo i trwałość twarogów i serów dojrzewających [Methods of packaging and safety and durability of tvarog and ripening cheese]. Przegl. Mlecz. 7, 269-272 [in Polish].

Ziółkowski T., Panfil-Kuncewicz H., Staniewska K., Szpendowski J., 2004. Durability of tvarogs produced with modified technology and packed with different methods. Pol. J. Nat. Sci. Supl. 2, 163-170. 


\section{WPEYW OPAKOWANIA I OKRESU POZYSKANIA MLEKA NA WYBRANE CECHY JAKOŚCIOWE EKOLOGICZNEGO SERA TWAROGOWEGO KWASOWEGO W CZASIE PRZECHOWYWANIA}

\section{STRESZCZENIE}

Wstęp. Celem podjętych badań było określenie wpływu okresu pozyskania mleka oraz sposobu pakowania na cechy organoleptyczne oraz wybrane wskaźniki fizykochemiczne sera twarogowego przechowywanego w warunkach chłodniczych.

Materiał i metody. Badania były prowadzone trzykrotnie: jesienią (październik), zimą (styczeń) i wiosną (na przełomie marca i kwietnia). Próby doświadczalne zapakowano próżniowo w folię PE o grubości 50 i $100 \mu \mathrm{m}$ oraz pergamin i folię PE o grubości 50 i $100 \mu \mathrm{m}$. Analizy wykonywano w dniu produkcji serów twarogowych oraz po 3, 7, 14 oraz 21 dniach przechowywania. Badane twarogi oceniano organoleptycznie oraz oznaczano w nich zawartość wody, tłuszczu, kwasowości, pH, twardość oraz określano procentowo ilość wycieku serwatki.

Wyniki. Spośród cech organoleptycznych najszybciej w czasie przechowywania następowało pogarszanie się zapachu wszystkich ocenianych serów twarogowych niezależnie od sposobu pakowania. Nie stwierdzono jednoznacznego wpływu sposobu pakowania na zawartość wody, tłuszczu oraz twardość serów twarogowych. Natomiast zaobserwowano, że zapakowanie sera dodatkowo w pergamin wpływało na zwiększenie ilości wydzielanej serwatki, ale jednocześnie korzystnie oddziaływało na jego strukturę i konsystencję.

Wnioski. Stwierdzono, że najbardziej pożądanymi cechami organoleptycznymi w czasie przechowywania odznaczał się ser twarogowy zapakowany w pergamin i folie PE o grubości $100 \mu \mathrm{m}$. Okres przydatności do spożycia, objętych badaniami serów twarogowych, niezależnie od sposobu pakowania oraz okresu pozyskania mleka, będącego surowcem do ich produkcji, wynosił do 7 dni.

Słowa kluczowe: ser twarogowy kwasowy, metody pakowania, pora roku

For citation - Do cytowania

Jasińska M., Harabin K., Dmytrów I., 2014. Effect of packaging and season of milk production on selected quality characteristics of organic acid curd cheese during storage. Acta Sci. Pol., Technol. Aliment. 13(3), 231-242. 